\title{
Infection with the new coronavirus in children
}

\author{
Infecţia cu noul coronavirus la copil
}

\author{
Mihaela Adela Iancu ${ }^{1,2}$, Oana Nicolescu ${ }^{3}$, Ioan Gherghina ${ }^{1,4}$, Dumitru Matei ${ }^{1,4}$ \\ ${ }^{1}$ Universitatea de Medicină şi Farmacie „Carol Davila“, Bucureşti \\ ${ }^{2}$ Cabinet medical individual, Bucureşti, România \\ ${ }^{3}$ Direcţia de Sănătate Publică, Bucureşti, România \\ ${ }^{4}$ Institutul Naţional pentru Sănătatea Mamei şi Copilului „Alessandrescu-Rusescu“, Bucureşti, România
}

\begin{abstract}
The first cases of the new coronavirus SARS-CoV-2 were reported for the first time in people in Wuhan, China in December last year. The infection with the SARS-CoV-2 virus spread quickly in China, followed by outspread in other countries. It was declared a pandemic in March 2020. SARS-CoV-2 causes the disease COVID-19, an acute severe respiratory syndrome. Infections were reported in children of all ages, from newborn to adolescence, with a smaller incidence than in adults, and having a better prognostic than in adults. A particular evolutionary feature of the SARS-CoV-2 infection in children is Paediatric Inflammatory Multisystem Syndrome (PIMS), a rare but severe disease which is associated with COVID-19 and which has been reported to have been diagnosed in children from Europe and North America. Paediatric Inflammatory Multisystem Syndrome has similar characteristics to those of the Kawasaki disease and concomitant infection of SARS-CoV-2. A small percentage of children who have been diagnosed with severe acute respiratory syndrome determined by SARS-CoV-2 require hospitalisation and very few require care in the intensive care unit. The prevention of COVID-19 focuses on hand hygiene, wearing face masks in enclosed spaces and social distancing.
\end{abstract}

Keywords: SARS-CoV-2, child, clinical features

\section{REZUMAT}

Primele cazuri de îmbolnăvire cu noul coronavirus SARS-CoV-2 au fost raportate pentru prima data la oameni în provincia Wuhan, China, în decembrie anul trecut. Infecţia cu virusul SARS-CoV-2 s-a răspândit rapid în China, apoi şi în alte ţări, fiind declarată pandemie în martie 2020. SARS-CoV-2 determină boala denumită COVID-19, un sindrom respirator acut sever. Au fost raportate infecţii la copiii de toate vârstele, de la nou-născut până la etapa de adolescent, cu o incidenţă mai mică decât la adulţi, având un prognostic mai bun decât la adult. Ca o particularitate de evoluţie a infecţiei cu SARS-CoV-2 la copii se descrie sindromul inflamator multisistem la copii (MIS-C), o afecţiune rară, dar gravă, asociată cu COVID-19, care a fost raportată la copiii din Europa şi America de Nord. Sindromul inflamator multisistem la copii are caracteristici clinice similare cu cele ale bolii Kawasaki şi infecţie concomitentă cu SARS-CoV-2. Un procent scăzut de copii diagnosticaţi cu sindrom respirator acut sever determinat de SARS-CoV-2 necesită spitalizare şi foarte puţini necesită îngrijiri în secţiile de terapie intensivă. Prevenirea transmiterii Covid-19 se concentrează pe igiena mâinilor, purtatul măştii în spaţii închise şi distanţarea socială.

Cuvinte cheie: SARS-CoV-2, copil, tablou clinic

\section{INTRODUCERE}

La sfârşitul anului 2019, erau raportate în China primele cazuri de sindrom respirator acut sever produs de un nou virus, din familia coronavirusuri- lor. Infecţia s-a extins rapid în China şi apoi în celelate ţări, astfel încât în luna martie 2020 a fost declarată pandemie de către OMS [1]. Transmiterea interumană a acestui virus a ridicat numeroase întrebări, la care încă nu avem răspunsuri, întrebări 
cu privire la factorii de risc care favorizează evoluţia severă, caracteristicile clinice, modalităţile de transmitere sau metodele eficiente de protecţie pentru lucrătorii din sănătate sau pentru contacţii persoanelor depistate pozitiv cu SARS-CoV-2. Lumea medicală este, de asemenea, preocupată şi de evoluţia viitoare a bolii [2].

\section{EPIDEMIOLOGIE}

În primele 5 luni ale acestui an, au fost înregistrate la nivel mondial aproape 7 milioane de cazuri şi peste 380.000 de decese [1]. Nu există date referitoare la vârsta celor afectaţi de infecţia cu SARSCoV-2. În România, au fost raportate peste 20.000 de îmbolnăviri, dintre care peste 1.400 de decese [3]. Conform Centrului Naţional de Supraveghere şi Control al Bolilor Transmisibile, 3\% dintre cazurile de îmbolnăvire din România au fost înregistrate la copii cu vârsta sub 9 ani şi aproximativ 4\% la copii cu vârsta între 10 şi 19 ani [3]. Până în prezent, în România nu au fost raportate decese la vârsta pediatrică [3]. Cazurile de îmbolnăvire la copiii din România au fost înregistrate predominant la băieţi [3].

Cele mai ample analize epidemiologice publicate au arătat, de exemplu, în China faptul că au fost raportate, din 44.672 cazuri confirmate de COVID-19, aproximativ 2\% îmbolnăviri cu virusul SARS-CoV-2 la copiii cu vârsta 0-18 ani, dintre care aproximativ jumătate sub 10 ani [4].

În Italia, un studiu publicat în martie 2020 arată că, din 22.512 cazuri confirmate de COVID-19, au fost înregistrate aproximativ 1,2\% îmbolnăviri cu virusul SARS-CoV-2 la copiii cu vârsta 0-18 ani. De asemenea, nu au fost raportate decese la vârsta pediatrică [5].

În SUA, în primele 4 luni ale acestui an, au fost înregistrate, din 149.760 cazuri confirmate de COVID-19, aproximativ 1,7\% îmbolnăviri cu virusul SARS-CoV-2 la copiii cu vârsta 0-18 ani. $\mathrm{Nu}$ au fost declarate decese la vârsta pediatrică [6].

\section{DATE GENERALE}

Virusul SARS-CoV-2 este un virus ARN, din familia coronavirusurilor. Se cunosc 4 genuri din această familie, care pot provoca boli respiratorii, enterice, hepatice sau neurologice la diferite specii de animale: genurile alfa, beta - prezente la lilieci şi rozătoare -, precum şi genurile delta, gama - prezente la diferite specii aviare. Încă din 1960, sunt cunoscute virusurile $\mathrm{HCoV}-\mathrm{OC} 43$ şi $\mathrm{HCoV}-\mathrm{HKU} 1$ (betaCoV) şi HCoV-229E şi HCoV-NL63 (al-
faCoV), care pot provoca infecţii uşoare şi autolimitante de căi respiratorii superioare la persoane imunocompetente. Aceste virusuri pot determina infecţii respiratorii inferioare la persoane imunocompromise şi la vârstnici. Celelalte tipuri de coronavirusuri cunoascute la om, reprezentate de SARS-CoV, SARS-CoV-2 şi MERS-CoV, au produs infecţii la om cu grad ridicat de severitate, cu manifestări respiratorii şi extrarespiratorii, cu transmitere interumană extinsă [7].

Structura genetică a virusului SARS-CoV-2 este identică în proporţie de $96,2 \%$ cu un virus identificat la liliac, diferenţele fiind înregistrate la nivelul proteinei membranare S. Aceste fragmente ale proteinei $\mathrm{S}$ sunt comune cu un coronavirus izolat la pangolin. Aceste două observaţii susţin evoluţia virusului SARS-CoV-2 de la liliac la pangolin şi apoi la om [8]. Pangolinul este un animal protejat împotriva vânatului (fiind cel mai vânat animal după elefant şi rinocer). Solzii pangolinului sunt folosiţi în medicina tradiţională chineză pentru tratarea mai multor afecţiuni: astm, artrită, infertilitate [8].

Unele studii arată o implicare în creşterea severităţii infecţiei cu SARS-CoV-2 aderarea virusului la peretele bacterian al Prevotella spp., bacterie prezentă în intestin; aceasta devine virulentă şi declanşează furtuna de citokine după aderarea virusului [9]. Numărul de bacterii Prevotella spp. prezent în intestine este mai mic la copii şi la persoanele cu greutate normală, cea ce ar putea reprezenta o explicaţie pentru cazurile severe întâlnite la vârstnici şi la persoanele adulte cu un indice de masă corporală peste $30 \mathrm{~kg} / \mathrm{mp}$. În acest sens, sunt necesare studii mai ample, studiile prezentate fiind puţine, cu lot mic de pacienţi [9].

\section{CARACTERISTICI CLINICE}

Raportul CDC (SUA) din 2 aprilie 2020 arată o afectare predominantă a băieţilor ( $57 \%$ dintre copiii afectaţi au fost băieţi). Analiza repartiţiei cazurilor pe grupe de vârstă prezintă afectarea în $20 \%$ dintre cazuri a sugarilor şi în peste $60 \%$ dintre cazuri a copiilor peste 10 ani. Un procent semnificativ dintre cazurile înregistrate la copii în SUA nu a necesitat internare, copiii fiind trataţi la domiciliu. $5-20 \%$ dintre cazuri au necesitat internare, procent variabil pe grupe de vârstă, cei mai mulţi fiind sugari. De asemenea, tot în rândul sugarilor a fost înregistrat cel mai mare număr de cazuri care au necesitat terapie intensivă (2\%). Cazuri severe au fost înregistrate în număr crescut şi la adolescenţi, mai ales la cei care aveau comorbidităţi [6]. 
Se pare că perioada de incubaţie la copil a infecţiei cu SARS-CoV-2 este mai scurtă decât la adult fiind în medie de 2 zile, cu un interval maxim de 10 zile [6].

Puţinele studii care au fost publicate până în prezent şi care analizează tabloul clinic al infecţiei cu SARS-CoV-2 la copil ne îndeamnă la prudenţă. Studiile arată particularităţi ale debutului bolii, dar şi ale evoluţiei.

De remarcat că triada reprezentată de febră, tuse şi dificultăţi în respiraţie a fost întălnită în mai puţine cazuri la copii decât la adulţi (73\% vs. 93\%) [6]. Raportul CDC a analizat şi prezenţa fiecărui simptom; febra este mai puţin prezentă la copil ( $56 \%$ vs. $71 \%$ ), tusea este prezentă în $54 \%$ dintre cazuri la copil, spre deosebire de adult, la care este prezentă în $80 \%$ dintre cazuri, iar dificultăţile în respiraţie sunt semnalate doar în 13\% dintre cazuri, comparativ cu $43 \%$ la adult [6]. În general, evoluţia infecţiei cu virusul cu SARS-CoV-2 la copil a fost asimptomatică sau paucisimptomatică, spre deosebire de adulţii diagnosticaţi cu COVID-19.

Un alt studiu, care analizează tabloul clinic al infecţiei cu SARS-CoV-2 la copiii din China, raportează prezența febrei în $40 \%$ dintre cazuri, peste jumătate $(60 \%)$ având valori ale temperaturii peste 38 de grade Celsius. De remarcat faptul că tusea a fost prezentă doar în jumătate dintre cazuri, 155 dintre cazuri au prezentat diaree prelungită, cu scaune numeroase, însoţită de dureri abdominale şi vărsături. Un procent ridicat de copii prezenta tahicardie $(42,1 \%)$ şi tahipnee $(28,7 \%)$. De asemenea, a fost observată evoluţia în majoritatea cazurilor $(65 \%)$ cu pneumonie. Aproape o cincime dintre cazuri, deşi aveau semne radiologice de pneumonie bilaterală, nu prezentau semne sau simptome de pneumonie [10]. Folosirea ecografiei point of care pentru examinarea pulmonară ar putea fi utilă pentru diagnostic, astfel că evaluarea rapidă ecografică permite detectarea anomaliilor chiar şi la pacienţii asimptomatici [11].

Cazurile pediatrice de COVID-19 sunt în general cazuri cu severitate medie, rar severitatea este crescută, dar coinfecţiile subiacente sunt mai frecvente la copii faţă de adulţi $[6,10]$.

Diareea a fost întâlnită în $15 \%$ dintre cazuri, spre deosebire de studiile pe adulţi, unde s-a observat o frecvenţă de apariţie mult mai redusă [6].

Deşi au fost raportate cazuri severe de COVID-19 la copii, inclusiv cazuri fatale, majoritatea copiilor par să aibă o boală cu evoluţie uşoară sau moderată şi se recuperează în 7 zile până la 2 săptămâni de la debutul bolii, recuperarea fiind mai rapidă decât la adult [12].
Sugarii cu vârsta sub 1 an şi copiii cu anumite comorbidităţi prezintă un risc mai mare de boală severă [13].

Factorii de risc implicaţi în evoluţia severă a infecţiei cu SARS-CoV-2 la copil sunt reprezentaţi de următoarele afecţiuni:

- bolile pulmonare cronice (în special astmul moderat până la sever şi fibroza chistică)

- bolile cardiovasculare (mai ales reprezentate de malformaţii cardiace)

- imunosupresia (cancer, chimioterapie, radioterapie, transplant)

- anomalii hematologice (siclemie, asplenie)

- boală renală cronică, fie că necesită sau nu dializă

- boală cronică a ficatului (hepatită cronică)

- sarcina la adolescente

- diabet zaharat tip 2

- obezitate, având indicele de masă corporală peste percentila 95 [13].

De ce infecţia cu SARS-CoV-2 pare să fie mai puţin frecventă şi severă la copil, comparativ cu infecţia la adult? Studiile viitoare ne vor arăta cu siguranţă raspunsul la această întrebare. Copiii prezintă un răspuns imun mai puţin viguros faţă de adulţi; un rol important poate fi reprezentat şi de interferenţa virală în tractul respirator la copiii mici, care duce la o încărcare virală mai mică la copii. Aşa cum ştim, receptorul pentru virusul SARS-CoV-2 este receptorul enzimei de conversie a angiotensinei 2, care poate fi exprimat diferit în tractul respirator al copiilor, comparativ cu adulţii [13]. Cazurile severe de COVID-19 au fost legate de niveluri crescute de procalcitonină şi interleukină la copil $[6,13]$.

Numeroase studii din Marea Britanie, Italia, Franţa, Spania şi Statele Unite ale Americii avertizează asupra prezenţei la copiii care au fost infectaţi cu SARS-CoV-2 a unui sindrom inflamator acut, multisistemic, cu evoluţie severă, asemănător cu boala Kawasaki[14].

Numărul cazurilor de sindrom inflamator Kawasaki-like, rar întâlnit la copii, a crescut considerabil în regiunile sever afectate de noul coronavirus, în special în Marea Britanie, Franţa şi Italia (de aproximativ 30 de ori) în primele luni ale acestui an [14].

Sindromul inflamator multisistemic potenţial asociat bolii COVID-19 asociază simptome similare şocului toxic şi bolii Kawasaki, tabloul clinic incluzând febra, erupţiile cutanate, conjunctivita bilaterală, modificările mucoasei cavităţii orale, edem plantar şi palmar, adenolimfopatie laterocervicală unilaterală. 
Un aspect particular este reprezentat de nounăscuţii care provin din mame infectate cu virusul SARS-CoV-2. În astfel de situaţii, se recomandă folosirea tuturor măsurilor preventive în momentul naşterii la femei diagnosticate cu COVID-19, din cauza riscului crescut de infecţie prin probabilitate crescută de aerosoli cu virus matern în timpul travaliului. Se recomandă ca nou-născuţii să fie separaţi de la naştere de mamele diagnosticate cu COVID-19, precum şi ca mamele să fie bine informate cu privire la riscul potenţial pentru nou-născut de a dezvolta infecţia cu SARS-CoV-2 [15].

Virusul SARS-CoV-2 nu a fost detectat până în prezent în laptele matern [15]. Se recomandă ca mamele diagnosticate cu COVID-19 să colecteze laptele matern în condiţii de igienă, astfel încât nou-născuţii pot fi hrăniţi cu lapte matern de către îngrijitorii neinfectaţi [15].

Nou-născuţii având mame cu infecţie documentată cu SARS-CoV-2 trebuie testaţi pentru SARS$\mathrm{CoV}-2$ la $24 \mathrm{~h}$ şi la $48 \mathrm{~h}$ de la naştere. Centrele cu resurse limitate pentru testare pot lua decizii individuale de risc/beneficiu cu privire la testare. Nounăscutul netestat necesită monitorizare ambulatorie prin telefon/telemedicină până la 14 zile după externare [15].

După externare, se recomandă păstrarea unei distanţe de aproximativ 2 metri între mamă şi nou-

\section{BIBLIOGRAFIE}

1. https://covid19.who.int - accesat 31.05.2020.

2. Diaconu C. A novel coronarovirus threatens the world. Arch Balk Med Union. 2020;55(1):11-13.

3. http://www.cnscbt.ro/index.php/analiza-cazuri-confirmatecovid19/1789-raport-saptamanal-episaptamana22/file accesat 09.06.2020.

4. Zhang Y. The Epidemiological Characteristics of an Outbreak of 2019 Novel Coronavirus Diseases (COVID-19) - China, 2020. Chinese Journal of Epidemiology 2020;2(8):113-112.

5. Livingston E, Bucher K. Coronavirus disease 2019 (COVID-19) in Italy. JAMA. 2020;323(14):1335.

6. Coronavirus Disease 2019 in Children — United States, February 12-April 2, 2020. MMWR Morb Mortal Wkly Rep 2020;69:422-426.

7. Sanda Maria Creţoiu. Structura genetică a noului coronavirus şi boala pe care o provoacă. Viața Medicală, 27 martie 2020.

8. Lam TT, Jia N, Zhang $Y$ et al. Identifying SARS-CoV-2-related coronaviruses in Malayan pangolins. Nature 2020.

9. Abdul Arif Khan, Zakir Khan. COVID-2019 associated overexpressed Prevotella proteins mediated host-pathogen interactions and their role in coronavirus outbreak. Bioinformatics 2020. născut, purtatul de către mamă a unei măş̧i, igienă riguroasă a mâinilor. Contactul între mamă şi nounăscut este permis dacă timp de 72 de ore mama nu a necesit utilizarea antipireticelor sau după 7 zile de la dispariţia simptomelor sau după 2 teste negative exsudat nazofaringian $\geq 24$ ore între ele, dacă există posibilitatea testării [15].

\section{CONCLUZII}

Copiii cu infectie cu SARS-CoV-2 pot să nu prezinte febră, tuse sau dificultăţi în respiraţie la fel de frecvent ca adulţii. Deşi majoritatea copiilor par să aibă o evoluţie uşoară sau moderată a infecţiei cu SARS-CoV-2, din cauza evoluţiei tabloului clinic se impune monitorizarea, în special în rândul sugarilor şi copiilor cu comorbidităţi.

Asocierea infecţiei cu SARS-CoV-2 cu prezenţa sindromului inflamator multisistemic la copil are consecinţe mult mai severe în rândul copiilor, în comparaţie cu estimările iniţiale. Distanţarea socială şi comportamentele preventive reprezintă măsuri importante de prevenţie pentru infecţia cu SARSCoV-2 pentru toate grupele de vârstă.

\section{Menţiune}

Toţi autorii au contribuit în mod egal la realizarea acestui articol.

Conflict of interest: none declared Financial support: none declared

10. Xiaoxia Lu et al. SARS-CoV-2 Infection in Children. N Engl J Med 2020;382:1663-1665.

11. Muntean PE, Neculcea CG. Chest imaging features of COVID-19 pneumonia. Arch Balk Med Union. 2020;55(2):361-362.

12. Gheorghe $\mathrm{G}$ et al. The Infection with new coronavirus SARS-CoV-2. Ro J Med Pract. 2020;15(1).

13. Ludvigsson JF. Systematic review of COVID-19 in children shows milder cases and a better prognosis than adults. Acta Paediatr. 2020;109:1088-1095.

14. https://www.cnscbt.ro/index.php/evaluare-de-risc/1729-ecdc-rra-paediatric-inflammatory-multisystem-syndrome-and-sars-cov-2-infectionin-children/file.

15. American Academy of Pediatrics Committee on Fetus and Newborn, Initial Guidance: Management of Infants Born to Mothers with COVID-19 - April 2, 2020. 